\title{
放送ニュース文を対象とした効果的類似用例検索法
}

\author{
田中 英輝 ${ }^{\dagger}$ 熊野 正 ${ }^{\dagger}$ \\ 浦谷則好什江原暉将什
}

著者らは用例提示型の日英翻訳支援システムを開発している。この中には利用者が入 力する日本語の表現に類似する表現を検索して, 検索結果を含んだ日本語文とその対 訳を表示する機能がある. 著者らの日本語データベースの文は平均長が 88.9 文字と 長い.このように長い用例を対象に類似検索を行う場合，キーワードによる AND 検 索は適切ではない. なぜなら用例が長いため 1 文中に同一キーワードが複数回出現す る場合があり，これが原因で不適切な用例を検索しやすくなるからである。これに対 して著者らは入力キーワードの語順とその出現位置の間隔を考慮した検索手法を提案 する．これによって構文解析を行うことなく構文情報を反映した検索を行うことがで きる. 本稿では従来の AND 検索と提案手法を使った評定者による主観評価実験を報 告する，この中で, 提案手法の有効性が統計的に有意となったことを示す.また, 検 索時間の増加は 1.3 倍であった.

キーワード：用例提示型翻訳支援システム, 類似性, 語順, $A N D$ 検索

\section{An Efficient Way of Gauging Similarity between Long Japanese News Expressions}

\author{
Hideki TANaka $^{\dagger}$, TAdashi Kumano ${ }^{\dagger \dagger}$, Noriyoshi Uratani $^{\dagger \dagger}$ \\ and Terumasa EHara ${ }^{\dagger \dagger}$
}

We are developing a Japanese-to-English Translation Aid system for news translators. The system consists of a voluminous bilingual news database whose sentences are properly aligned across languages beforehand, and a similar expression search engine. A user can find past translation examples of input Japanese with the system. Similar expression search engines like the one in this paper have usually employed an AND retrieval technique that uses keywords in the input expression, to measure the similarity between the input and the target by the number of shared keywords. In many cases of applying such search engines to our database, however, a number of spurious search results have been produced as a consequence: the sentences have been quite long (88.9 Japanese characters on average) and a single sentence has often contained identical keywords many times. In this paper, we propose adding two constraints to the AND retrieval technique: the order and positions (deviations) of keywords. We enhance AND retrieval allowing it to be able to reflect some syntactic similarity by this inexpensive modification. We will show, through a set of experiments, that the proposed method significantly improves the level of user satisfaction in search results in a statistical sense, with only a 1.3-fold increase in the search time.

KeyWords: Example-Based Translation Aid System, Similarity, Word Order, AND Retrieval 


\section{1 はじめに}

人間の翻訳作業を支援するシステムは，電子単語辞書から機械翻訳システムまでいろいろ提 案されており関連する研究も多い (Isabelle and Church 1997). 著者らはこの中の用例提示型の 翻訳支援システムの研究を行っている。このシステムは一般的に巨大な対訳用例データベース と検索システムから構成される。このシステムに対して利用者は「翻訳がわからない」と思う 表現を入力する，するとシステムは入力に一致した表現，あるいは類似した表現をデータベー ス中で検索してその翻訳例を提示する．利用者は提示された翻訳例を参考に翻訳を作成する.

機械翻訳システムと違ってこの場合の翻訳の主体は利用者にあり，システムは利用者に参 考となる情報を提示するだけである。このように利用者主体の翻訳作業を支援する考え方は Kay(Kay 1997) によって 1980 年に提案されている。この文献では電子化辞書を使った支援を 提案しているが，対訳用例を使う翻訳支援もこの考えを基本的に踏襲したものである．また実 際に対訳用例を使って日英翻訳支援システムを作成した例としては (中村 1989; 隅田, 堤 1991) 等の先駆的なシステムがある.さらに最近では商用システムもいくつか販売されている.

著者らは上記一連の研究と同一の考えに基づいて，日本語ニュースの英訳支援のためのシス テムを開発している。このシステムには二つの特徵がある。一つは利用する日英用例の対応付 けの粒度である，従来の研究では，表現の対応を集めた日英表現翻訳辞書や文間の対応付けを 行ったデータベースなど詳細な単位で対応のとれたデータベースを利用することが多かった。

これらに対して著者らのデータベースは記事という大きな単位での対応はとれているが，そ れより細かな対応はとれていない。これは日本語ニュース記事を英訳する場合に, 英語視聴者の 背景知識や興味に合わせて大きく意訳することがあるためである，極端な場合は日本語ニュー スを参考にして英文ニュースを新なに作成する場合もある.

このため入力の検索結果に対応する翻訳部分を提示するには，日英表現の自動的な照合が必 要になる。そしてこの場合に表現が照合しないことも前提にしなくてはならない.

第二点は「意訳の支援」である，従来，用例提示型のシステムはマニュアル翻訳のような定 型的な翻訳に応用する場合が多かった。たしかにニュース翻訳の場合でも「株価」「天気予報」 「新車販売台数月例報告」などの項目はほぼ定型的な文から成り立っており，これらを有効に支 援できると思われる。

しかし著者らは本システムで意訳を積極的に支援したいと考えている。なぜなら意訳こそ ニュース翻訳の難しい部分であり，また用例によって有効に支援できると考えるからである．例 えば日本語の短い言い回し「いかがなものか」は本稿のデータベース中だけでも過去 10 通り 程度に訳されている，同様に同じ単語や似たような文が文脈によってどのように意訳されてい るかを観察すれば，意訳のための知識を効果的に学ぶことができると考える.

$\dagger$ ATR 音声翻訳通信研究所, ATR Interpreting Telecommunications Research Laboratories †† NHK 放送技術研究所, NHK Science and Technical Research Laboratories 
意訳であろうと定型的な翻訳を支援する場合であろうと，表現を検索する部分には同じ手法 を利用できる。しかし，結果の表示には異なった配虑が必要である，定型的な翻訳であれば入 力に対応する翻訳例を一つ示せば十分である。しかし意訳を支援するにはできるだけたくさん の翻訳例を文脈付きで利用者に提示する必要がある。このため著者らのシステムは検索速度を 重視している. またどのような長さの入力であっても出力は日本語と英語の記事を提示した上 で，対応個所を強調して表示している.

本稿は上記のシステム中の検索部分を対象としている，著者らは一文字から一記事までの範 囲を入力として類似検索ができるシステムを研究している。これは意訳が単語や短い表現から 文や記事までの広い範囲で行われるためである。

実際には一文字から一文までを対象にした検索システムと記事を対象にした検索システムの 二つを作成した．本稿はこのうちの一文までの表現を対象として類似用例を検索する手法につ いて報告する。

著者らはこの検索を頑健で柔軟かつ高速に行うためキーワードの AND 検索を基本的な手法 として採用した. すなわち, 入力を形態素解析してあらかじめ指定している品詞のキーワード を抽出して AND 検索を行う手法である. しかし単純な AND 検索を行うと不適切な結果を多 数表示することが判明した.

そこで著者らは AND 検索に語順と「変位」と呼ぶ制限を加えることを提案する。これは表 層的な情報を利用して AND 検索に構文的な情報を反映させようという試みである。この手法 は構文解析を利用していないため速度と頑健性に優れている。

以下，本稿の構成を示す. まず 2 章で著者らの用例提示型翻訳支援システムの概要を説明し て，この中の類似用例検索部分の設計方針を示す. 3 章では類似用例検索にキーワードによる AND 検索を利用した場合に起こる問題を示す．続く 4 章では AND 検索に語順と変位を使う 手法を提案する。またこの手法を使った検索手順をアルゴリズムの形で示す。そして 5 章で約 160 万用例からなるデータベースを使った検索実験を報告する。ここでは検索時間と, 検索結 果の主観的な満足度などを報告し, 提案手法は AND 検索にくらべてわずかに検索時間が増加 するものの（約 1.3 倍）利用者の満足度は統計的に有意に優れていたことを示す. 次に 6 章で は関連研究を紹介して本研究との比較を行い最後に 7 章で本稿のまとめを行う.

\section{2 用例提示システムの概要}

\section{1 構成}

用例提示システムは下記の部分から構成されている.

・ 日本語と英語の 2 言語ニュース記事データベース

- 日本語類似用例検索システム 
表 1 日本語部分のデータベースの規模

\begin{tabular}{l|r}
\hline \hline 記事数 & 94,830 件 \\
文の数 & $1,615,119$ 件 \\
バイト数 & $104 \mathrm{MB}$ \\
\hline
\end{tabular}

- 検索結果の表示システム

このシステムは次のような形で利用する。まず英訳したい日本語ニュース記事がある。この 中で翻訳を調査したい表現があればこれをシステムに入力する。このとき利用者は表現を編集 せず，カットアンドペーストで入力することを想定している．システムは入力に一致する表現， あるいは最も近い表現を日本語記事データベースで検索する，結果は日本語，英語とも記事を 表示単位として，日本語の検索結果を含む文とそれに対応する英文を強調して表示する．記事 を単位として表示するのは，文脈を利用者に提供することが重要な゙と考えるからである，ユー ザは提示された過去の翻訳例を参照して自分の翻訳を作成する。もし結果に満足できなければ 次の検索結果をシステムに要求する.

\section{2 データベース}

2 言語記事データベースは NHK の日本語ニュース記事とその人手による英訳を 1995 年 3 月から 1997 年 2 月までの期間蓄積して作成したものである。表 1 に本稿のシステムで使った 日本語記事データベースの大きさを示す 1 ．また，英語の部分もほぼ同じ規模である。

英語のニュース記事は日本語の記事全体を元にして作成しており，日本語文の単純な直訳を 集めたものではない。これは英語視聴者の視点に立った分かりやすいニュースを作成するため に意訳が求められるからである。このため文間の対応関係を単純に求めることは難しい。そこ で (熊野, 田中, 浦谷, 江原 1997) で提案された手法を使って対応付けを実施した.

さらに任意の日本語文字列を高速に検索できるように日本語データベースに対してポインタ 表現の部分列インデックスを作成した (長尾 1996).このインデックスにより，任意長の入力文 字列の出現位置を漏らさず高速に求めることができる。この時，どの記事のどの文に出現した かもわかるようにインデックスを作成している.

\section{3 検索部分の設計方針}

1 章で述べたように著者らはこのシステムを使って定型的な翻訳だけでなく意訳を支援した いと考えている。この目標はシステムの想定利用者であるニュース翻訳者への面接調査を行っ て設定した，翻訳者は日本語，英語とも基本的に堪能である。しかし経験によってはニュース 翻訳の知識が十分でない場合がある。面接調査によると,「固有名詞」や「複合語」などの主に 索ではこれらすべてを対象としている。記事内容を表す文は 446,444 件 (76 MB) である. 
定型的翻訳を行う表現と, 単語, 表現, 文, 記事のさまざまな段階で必要になる意訳を支援し てほしいという要求があった。

定型的翻訳，意訳とも多種類の表現が対象になる。そこで著者らのシステムではさまざまな 長さの入力に対して検索できるようにした，具体的には一文字から一文までを入力対象にした 検索システムと記事を入力対象にした検索システムの二つを作成した。棟語ニュース記事は 5 文程度からなっており段落がない，そこで実用上はこの分類で十分と考えたからである。本稿 はこのうちの一文までの文字列を入力として類似用例を検索する手法について報告する お本稿ではこの検索システムを表現検索システムと呼ぶ.

表現検索システムには次の 2 種類の検索機能がある.

- 完全一致検索

一文までの範囲の文字列を入力してこれに完全に一致する表現の出現位置を 2.2 節のイ ンデックスを参照して漏らさず求める。この結果，これを含む記事と文とその中の位置 を特定することができる，長い入力に対しては結果が得られない可能性が高いが，慣用 的な表現を検索するのに有効である

- 類似検索

入力文字列を形態素解析して自立語を抽出しこれをキーワードとする ${ }^{3}$.データベース中 の日本語の各文を対象にキーワードをなるべく多く含む文を検索する。すなわち入力表 現と用例文の類似性は共有するキーワードの数で評価するキーワードの出現位置は上 記の完全一致検索を利用することで高速かつ完全に求めることができる．キーワードの 組み合わせによる検索もあとで述べるように高速に実現できる。なお類似検索は一文を 検索対象とするため，以後，一文と用例を同じ意味で使用する 類似検索は次のような手順で実行する。また具体例は図 1 に示す.

（1）最初はすべてのキーワードを含んだ用例を検索する。成功すればそれらを表示する。

（2）もし，検索に失敗するか，成功しても利用者がさらに検索を要求した場合にはキー ワード数を一つ減らして検索を続ける。この時一度表示した用例は検索の対象としな

い.なぜなら同じ用例を提示しても利用者は新なな情報を得られないからである。 このようにキーワード数の条件を利用者の指示で徐々に緩和して検索を実行する．条件を緩和 する場合にはキーワードすべてが同じ重要性を持つと仮定して，任意のキーワードが一つなく なった条件で検索を行う。

ここで提案した検索は特殊な処理を想定していないため頑健である。またキーワードの選択 方法，キーワードの緩和方法を変えることでさまざまな検索を実現できるため柔軟性も高い. このため将来の拡張も比較的簡単である。また高速なため，満足な解が得られない場合は何度

2 記事を入力とした検索および閲覧システムに付いては (田中, 熊野, 松田 1997; Tanaka 1997; Tanaka, Kumano, Uratani, and Ehara 1999) を参照されたい.

3 このとき活用する自立語は活用形に展開し, さらに間違ったキーワードを検索しないように接続し得る機能語を付与し た展開を行う. 4.4 節参照. 
入力表現：円高の勢いは一向に衰えず

形態素解析・キーワード抽出・活用語の語尾展開・機能語付加

巴 and 勢い and二向 and (衰える or 衰えな or 衰えろ or 衰えよor …)

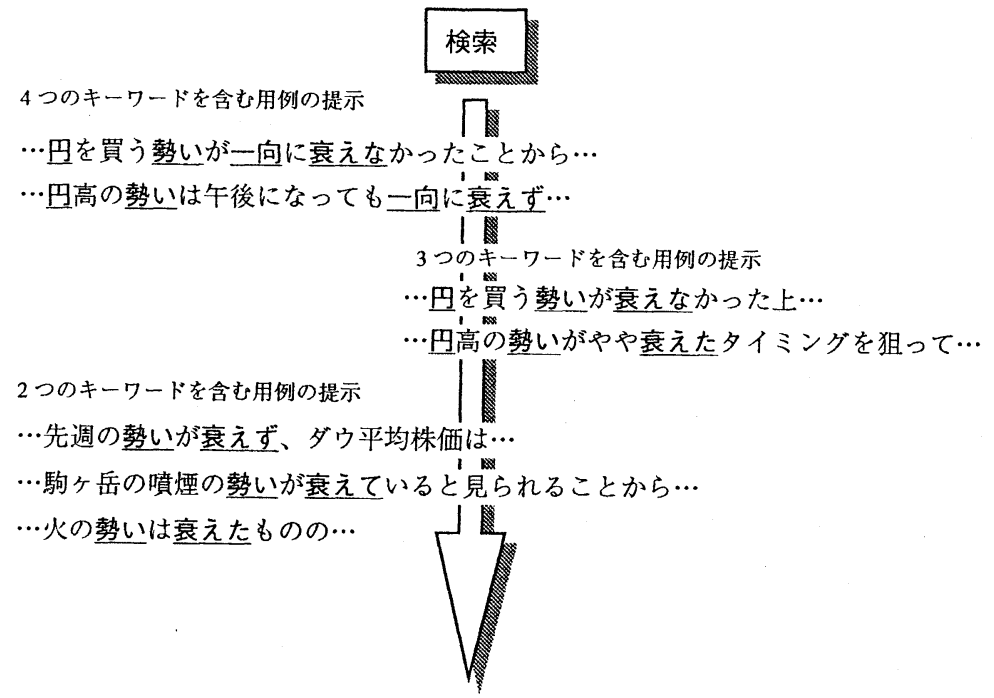

図 1 類似検索概念図

でも検索できる．さらに類似検索の結果を提示する場合も根拠としてキーワードを提示できる ため直感的な理解が容易になる。なお，完全一致検索はポインタ表現の部分列インデックスを 参照することでそのまま実現できるので以降では類似検索部分のみ議論する.

\section{$3 \mathrm{AND}$ 検索の問題点}

2 章で述べた類似検索を実現するにあたり著者らは最初キーワードの AND 検索を採用した (Salton and McGill 1983).すなわち入力キーワードと検索対象中のキーワードの語順の一致を 考虑しない手法である.

AND 検索を採用した理由の 1 つは高速性である.データベース中での各キーワードの出現 位置さえわかれば，これらを AND 条件で含む記事を特定するのは容易で高速である．もう 1 つの理由は 6 章で述べるように AND 検索を採用した用例検索システムが多く提案されており 効果的であると報告されていたからである.

しかし日本語ニュース原稿を対象に AND 検索を使うと問題が発生することが明らかになっ

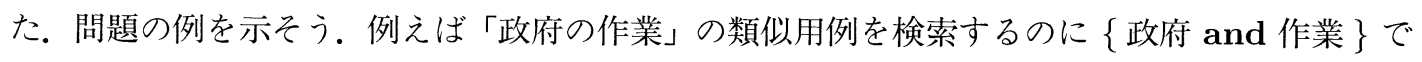


検索すると下記の文をすべて出力する，尚，用例中の照合キーワードを太字で強調している。

例 1

外務省の橋本外務報道官も，きのうの記者会見で,「保証人委員会は一生懸命作業 をしているが，ペルー政府と武装グループが，保証人委員会の努力を受け入れる 所まで事態は進んでいない」と述べました。

例 2

この問題に関する自民党の対外経済協力特別委員会が今日午後開かれ，政府側は， 「中国は去年七月に核実験を行なった後，今後の核実験を凍結すると表明してお り，無償資金協力の再開に向けた準備作業を進めていきたい.」と述べました。 例 3

また池田外務大臣は,「日本政府とペルー政府との間は信頼関係が出来ている」と 述へ，両国政府の間で緊密に連絡を取っていることを明らかにするとともに，今 後の日本の役割について「関係国の間で，バラバラの対応にならないよう，国際 社会が一致してペルー政府の進め方を支えていくことが重要だ。日本政府は，事 件の解決に向けたペルー政府の作業がうまく運ぶよう，条件を整える努力をして きており，今後はこうした努力が一層大切になる」と述べました。

例 1 には「政府」「作業」というキーワードが一文中に出現している。しかしこの順序が逆 転しており，またその間に関連がなく類似用例とは考えられない，例 2 では 2 つのキーワード が出現しており語順も入力と同じである。しかし両者に係り受け関係はないため類似用例とは 考えられない. 例 3 では「政府」が 6 個所,「作業」が 1 個所出現している。この中で，下線部 が入力表現と一致しており用例 3 は類似用例と判断できる。しかしこの用例には「政府」が 6 個所も出現しているため下線がなければ該当個所を見いだすのは容易ではない.

ここで使った入力表現「政府の作業」は短いため，この中に重複するキーワードはない．し かし長い入力表現では同じキーワードが出現する可能性がある。この場合，照合部分を把握す るのはさらに困難になる。

まとめると AND 検索の問題は例 1 と例 2 で示したような不正解文を拾いやすいこと, 正 解であっても例 3 のように該当個所を確認しにくいことである.このような問題が発生する主 な原因は日本語ニュースの文の平均長が 88.9 文字 (熊野, 田中, 金, 浦谷 1996) と長いことにあ る. 短い用例を使ったシステムではこのような問題は発生しにくいであろう.

これらの問題を解決するには構文解析を利用する手法が考えられる。 入力のキーワード間 の係り受け関係を認定して, 同様の係り受け関係を持つ用例を検索する手法である (兵藤, 池田 1994). しかし現時点では構文解析器の精度が十分でないためこの手法は採用しにくい.そこで 著者らはこれらの問題を構文解析せずに 4 章で提案する近似的な手法で解決することにした。 


\section{4 提案手法}

単純な AND 検索手法には 3 章で述べた問題がある。またこれらを解決するのに構文解析を 使うことは困難である。そこで著者らは AND 検索に語順と変位とよぶ制約を加えた検索手法 を考案した，尚，以下ではこの手法を AND+W+D（AND + Word order + Deviation）検索 とよぶ。この手法は構文解析をせずに，表層の単語のならびと位置情報を使って近似的に構文的 な情報を捉えたものである，本章では AND 検索，AND 検索に語順を加えた検索（AND+W 検索）について説明し，その上で提案手法（AND+W+D 検索）を説明する。次にその実装ア ルゴリズムを説明する。

以下では次の入力例を用いて説明を行う。

$$
\text { 入力表現 } * * \mathrm{~A}^{*} \mathrm{~B} * * \mathrm{~A}^{*} \mathrm{C}^{*}
$$

ここで “A，B，C”はキーワード，“*”はそれ以外の単語とする。また簡単のためキーワードや 単語はすべて一文字とする。

\subsection{AND 検索}

$\mathrm{AND}$ 検索では次の 4 つの用例をすべて出力する。ここでは用例中の照合したキーワードを 強調表示している.

$$
\begin{array}{ll}
\text { 用例 } 1 & { }^{*} \underline{\mathbf{A}}^{* *} \underline{\mathbf{B}}^{*} \underline{\mathbf{C}}^{* *} \underline{\mathbf{A}}^{* *} \\
\text { 用例 } 2 & { }^{*} \underline{\mathbf{A}} \underline{\mathbf{A}}^{*} \underline{\mathbf{B}}^{* *} \underline{\mathbf{C}} \\
\text { 用例 } 3 & * \underline{\mathbf{A}}^{* *} \underline{\mathbf{A}}{ }^{* *} \underline{\mathbf{B}}^{*} \underline{\mathbf{A}}{ }^{* *} \underline{\mathbf{C}} \\
\text { 用例 } 4 & { }^{*} \underline{\mathbf{A}}^{* *} \underline{\mathbf{A}}^{*} \underline{\mathbf{B}}{ }^{* *} \underline{\mathbf{A}}{ }^{*} \underline{\mathbf{C}}
\end{array}
$$

これらの用例は順序が違ってもキーワード “A, B, C”を含んでいるので条件を満たす。ま た 4 つの用例の間に優先順位はない.

用例 3 と用例 4 には “A”が 3 つあるが，この中のどの 2 つと照合したかを決めることが できない ${ }^{4}$. 以上の問題は先に 3 章の例 3 で具体例で説明した問題と同一である.

\section{2 語順を考慮した AND 検索}

入力と語順が同じ表現はそうでない表現より近いであろう。なぜなら語順はある程度構文の 情報を担うからである。そこで AND 検索に語順の制約を付加することで類似性の低い不適切 な検索結果を減らせると期待できる，例えば上記の例でキーワードの語順を考慮して検索する と用例 3 と用例 4 だけが出力される。 3 章の例で言うと,「政府の作業」に対して例 2 と例 3 だけに解を絞ったことに相当する.

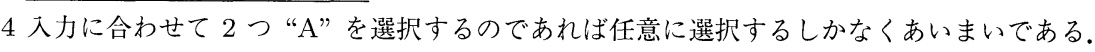




\section{用例 $3 * \underline{\mathbf{A}}^{* *} \mathrm{~A}^{* *} \underline{\mathbf{B}}^{*} \underline{\mathbf{A}}^{* *} \underline{\mathbf{C}}$ \\ 用例 $4 \underline{\mathbf{A}}^{* *} \mathrm{~A}^{*} \underline{\mathbf{B}}^{* *} \underline{\mathbf{A}}^{*} \underline{\mathbf{C}}$}

しかし，語順だけでは不十分な点がある。まず用例 3 と 4 には最初に A が 2 つるがどちら が照合キーワードなのか決めることができず照合個所を特定できない.また用例の間に優先順 位をつけることができない.キーワードの数と語順が同じ用例が検索されたときにその提示の 優先順位を決められない問題である。これは大規模なデータベースを対象にした場合に結果を 絞り込めない問題につながる.

\section{3 語順と変位を考慮した AND 検索}

著者らは上記の問題を解決するために以下で説明するキーワードの「変位」を使った手法を 利用した。

まず入力中のキーワード $x_{i}$ の出現位置を与える関数を $\operatorname{org}\left(x_{i}\right)$ とする。この值は任意の キーワードについて一意に決めることができる．これに対してキーワード $x_{i}$ の用例内での出現 位置を与える関数を $\operatorname{pos}\left(x_{i}\right)$ とする ${ }^{5}$ 。もし $\operatorname{pos}\left(x_{i}\right)$ の值が決まればキーワード $x_{i}$ を入力と用 例で照合できることになる。しかし，現在の例のように用例に同一キーワードが複数出現する 場合には一意に照合できない。

ここで入力中の $x_{i}$ の右隣のキーワードが $x_{i+1}$ であるとする. また用例中にも $x_{i}$ と $x_{i+1}$ と同じ 2 つのキーワードが出現しているとする.ただし用例にはこの 2 つのキーワードが複数 出現しておりキーワードの対応があいまいだとする，この時，次式で定義するキーワード対の

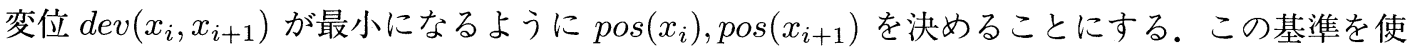
えば変位が同じ場合を除いて一意に照合することができる.

$$
\operatorname{dev}\left(x_{i}, x_{i+1}\right)=\left|\left(\operatorname{org}\left(x_{i+1}\right)-\operatorname{org}\left(x_{i}\right)\right)-\left(\operatorname{pos}\left(x_{i+1}\right)-\operatorname{pos}\left(x_{i}\right)\right)\right|
$$

（1）式は入力のキーワード対の間隔と用例のキーワード対の間隔の差である。これが最も 小さくなるように照合するのは，キーワードの間隔が似ている場合には係り受け関係も近い可 能性があると考えたからである．例えばこの経験則で 3 章の例 3 の「政府の作業」の照合を正 しく行うことができる.

一般に入力のキーワードが $n(n \geq 2)$ 個ある場合には隣接キーワード対の変位を利用して, その合計が最小になるように照合する ${ }^{6}$.

$$
\sum_{i=1}^{n-1} \operatorname{dev}\left(x_{i}, x_{i+1}\right)
$$

5 org $\left(x_{i}\right), \operatorname{pos}\left(x_{i}\right)$ は差をとるためデータベース中での絶対位置であっても文毎の相対位置であってもかまわない. 以下 では文毎の相対位置とする。

6 隣接キーワード一組では必ずしも構文の近さを反映しない場合がある.「政府の作業」と「政府に作業」は係り受けは違 うが変位は 0 である.キーワードが増えて制限が強くなるほど構文的近さの良い近似になる傾向がある。 
現在の例で入力には $\{A, B, A, C\}$ というキーワードがある.そこで $\operatorname{dev}(A, B)+\operatorname{dev}(B, A)+$ $\operatorname{dev}(A, C)$ が最小となるようキーワードを対応させる。また，この值の小さな順に用例を提示 する。この結果は次の通りである.

\section{用例 $4{ }^{*} \mathbf{A}^{* *} \underline{\mathbf{A}}^{*} \underline{\mathbf{B}}^{* *} \underline{\mathbf{A}}^{*} \underline{\mathbf{C}}$ 変位合計 0 \\ 用例 $3 * \mathbf{A}^{* *} \underline{\mathbf{A}}^{* *} \underline{\mathbf{B}}^{*} \underline{\mathbf{A}}^{* *} \underline{\mathbf{C}}$ 変位合計 3}

$\mathrm{AND}+\mathrm{W}$ 検索と同じ用例を検索しているが，照合したキーワードを特定できており，また 検索用例に順位がついていることに注意されたい.

ここで $\mathrm{AND}+\mathrm{W}+\mathrm{D}$ 検索の特徴をまとめる.

・ キーワードのあいまい性の解消

$\mathrm{AND}+\mathrm{W}+\mathrm{D}$ 検索はキーワード照合にあいまい性がある場合にそれを解消する能力があ る. 3 章の例 3 の場合では「政府」の照合個所を下線部分に特定できる。この性質は結 果を表示する場合に有用である。

- 用例の順位付けが可能

$\mathrm{AND}+\mathrm{W}$ 検索 と $\mathrm{AND}+\mathrm{W}+\mathrm{D}$ 検索が同じ入力キーワード群で出力する用例集合は上記 の例のように常に一致する. 違いの一つは用例に優先順位がつく点である. 例えば, 3 章 の例の例 2 と例 3 のキーワード数は 2 で同じである。しかし例 3 の変位合計は 0 であ るため 1 位となり例 2 は变位が大きいので 2 位の解となる.

- 完全一致検索に近い

名詞複合語を検索する場合は構成要素の名詞が連続した用例が正解である。 AND +W +D 検索ではもし入力と同一の複合語があればその変位合計は 0 となって第 1 位で出力され る.すなわち完全一致検索の機能も包含した検索手法となっている。一方，AND+W 検 索ではこのような保証はない。この性質は特に名詞複合語の検索が多くなる場合に有利 である。

一般的に AND 検索 は同じ入力キーワード群に対して語順を考慮した AND $+\mathrm{W}$ 検索 と $\mathrm{AND}+\mathrm{W}+\mathrm{D}$ 検索より多くの文を検索する傾向がある。ただし，キーワード数を 1 まで減らし て検索できる文の集合はいずれの手法も同じである。すなわちデータベース中の類似用例の正 解がどう定義されていても最大限に条件を緩和すれば 3 手法の再現率は同じことになる.

\section{4 アルゴリズムの概要}

類似検索全体のアルゴリズムは 2.3 節に示した手順に従っている.すなわち利用者の要求に 従ってキーワードの数を一つずつ減らして検索を行う。このとき利用者は途中で検索を打ち切 ることが可能である7 . また，用例はキーワードを最大個数含む段階で表示するものとし，それ 以後のキーワードを削減した段階では表示しない。ここでは上記を考虑した AND+W+D 検索 7 実際，キーワード数が一つになるまで条件を緩和することは考えにくい. 
アルゴリズムの概要を説明する，処理の大まかな流れは以下の通りである.

- 入力表現の形態素解析を行ってキーワードを求める

・用例集合中でのキーワードの出現位置を完全一致検索で求める

・ キーワードが出現している用例についてはノードテーブルを作成する，ノードテーブル は検索に使うデー夕構造である

・ 検索, 表示処理のループ. ユーザの要求によって繰り返す

- 検索処理

- 表示処理

入力表現は形態素解析されて自立語がキーワードとして抽出される.キーワードのうち活 用語は活用語尾や「な（い）」「つつ」など接続し得る機能語をすべて付加して展開する．本シ ステムではキーワードの出現位置を文字列検索（完全一致検索）によって求めている。このた め活用するキーワードは可能な出現形で検索する必要がある。このとき活用語尾を付加しただ けでは間違った品詞のキーワードを検索する場合がある。例えば一段動詞の未然形や連用形の 「衰え」を検索すると名詞の「衰え」を検索する恐れがある。このため機能語も付加して検索す ることで誤検索を防いでいる，ただし，例えば否定の「ない」は「なかっ」「なかろ」「なく」 「ない」「なけれ」と活用するが「な」だけを付加する。つまり誤検索を防ぐのに必要十分な機 能語部分文字列を付加する戦略を取っている.

入力には同じ表層形のキーワードが複数出現する場合があるため，出現順に付番してすべて を区別する。この番号をキーワード id と呼ぶ。ただし展開で得られる派生キーワードは同一の キーワード id とする.

全用例集合を対象に各キーワード表層形を完全一致検索によって検索し，それぞれが出現し た用例とその中での位置を求める。キーワードが一つ以上出現している用例については，ノー ドテーブルと呼ぶデー夕構造を作成する.

前節で使った入力と 4 つの用例に対応するノードテーブルの例を図 2 に示す.

この図の最上段は入力のキーワードの出現位置を示している．下部の $g_{1}$ から $g_{4}$ に示した ノード群が用例 1 から 4 に対応するノードテーブルである.このテーブルは入力のキーワード を出現順，つまりキーワード id 順に並べ，各 id のキーワード表層形の出現位置をノードとし て記述している．各ノードは対応するキーワード id で管理されている8

ここで入力中にキーワードが $M$ 個あるとする。このノードテーブルには次の性質がある.

（性質 1）用例のノードテーブルに対して任意のノードから右方向でかつ出現位置が増加する ような経路を作成したとする。この経路上のノード集合は語順の条件を満たすキーワー ド集合である，図 2 の矢印が経路の例である，以後，経路とはこの条件を満たす経路で あるとする。

8 活用する語の場合には同一キーワード id に複数の表層形があり，そのすべての出現位置を同一キーワード id 下のノー ドとする。 


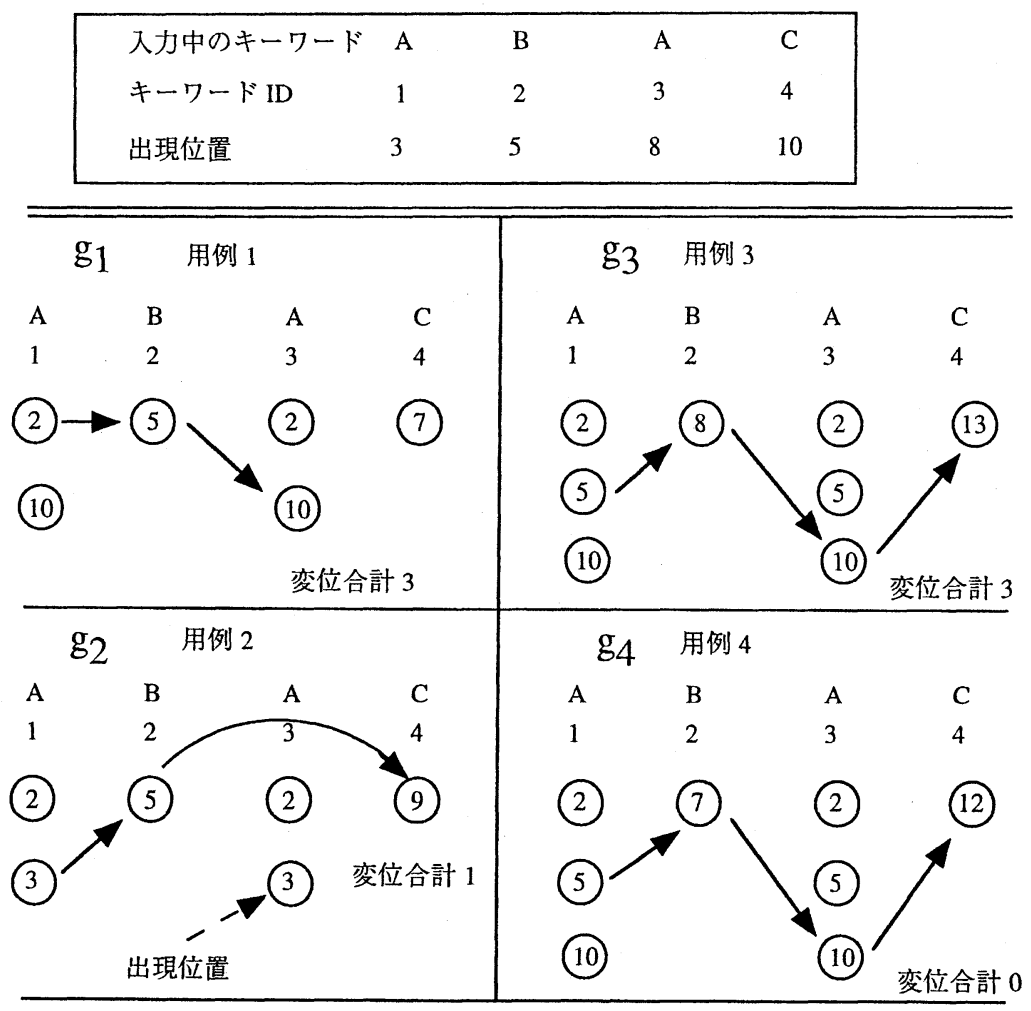

図 2 ノードテーブルと検索結果

任意のノードからの経路を求める場合に，ノードをなるべく多く含んでかつ変位合計が 最小となる経路はグラフの最短経路問題として定式化できるので従来のアルゴリズムで 高速に求めることができる ${ }^{9}$.すなわち各ノードを始点とする最適な検索結果を求めるこ とができる。

(性質 2) $N$ 個のキーワードを含む経路はキーワード id が $M-N+1$ 以下（左）であるノ一 ドを開始点とする経路上にしかない，例えば図 2 においてキーワード数 3 の経路はキー ワード id が 1 のノードと 2 のノードを開始点とする場合しかない.

別な見方をするとキーワード id が $M-N+1$ に属するノードを開始点として経路を求 めると，N 以下のキーワードを含む場合の経路を求めることができる.

以上の性質を利用して図 3 に示す $\mathrm{AND}+\mathrm{W}+\mathrm{D}$ 検索を実現した。

アルゴリズム中の変数 $S$ は全用例集合を示す $S=\left\{s_{1}, s_{2}, \ldots s_{i}, \ldots\right\} . G$ は検索対象の用例 の番号を記録するリスト変数である（b5）。一度表示した用例はこのリストから削除すること で以降の処理を行わないようにする $(\mathrm{d} 3)$. 
a1） 入力のキーワードを抽出，展開する;

a2）用例集合でのキーワードの出現位置（文と位置）をすべて求める;

a3) $\quad M$ キーワード数;

a4) $\quad N=M$;

b1) $\quad G \leftarrow \emptyset$;

b2) foreach $\left\{i \mid s_{i} \in S\right\}\{$ 全用例に対して

b3) if (用例 $s_{i}$ がキーワードを一つ以上含むならば) \{

b4）用例 $s_{i}$ のノードテーブル $g_{i}$ を作成する;

b5) $G \leftarrow G \cup\{i\}$; 検索対象用例リス卜を作成する

b6) $\quad\}$

b7) \}

c1) while $(N>0)\{$

c2) startId $=M-N+1$; 開始点のキーワード id の設定

c3) foreach $\{i \mid i \in G\}\{$ 検索対象用例 $i$ に対して

c4) foreach $\left\{n \mid g_{i}\right.$ の startId に属する各ノード $\}\{$

c5-1） $g_{i}$ のノード $n$ から始まる最適経路を求める

c5-2）最適経路上のノード数を num

c5-3) 変位を newdev

c5-4） キーワード出現位置リストを list とする

c6)

c8)

c9)

if $(R(i) \cdot d e v>$ newdev $)\{$

$R(i) . d e v \leftarrow$ newdev;

$R(i) . k w d \_n u m \leftarrow$ num;

$R(i) . k w d_{-}$list $\leftarrow$ list;

d1) foreach $\left\{i \mid i \in\left\{R(i) . k w d \_n u m=N\right\}\right\}\{$

d2） devの小さい順に用例 $i$ とその照合キーワードを表示する;

d3) $G \leftarrow G-\{i\}$; 表示した集合を対象用例から削除する

d4) $\quad\}$

d5) if ( 利用者が終了を指示 or $G=\emptyset)\{$ 終了; $\}$

d6) else $\{N \leftarrow N-1$; $\}$

d7) $\}$

図 $3 \mathrm{AND}+\mathrm{W}+\mathrm{D}$ 検索の基本アルゴリズム

$R(i)$ は用例 $s_{i}$ に関する情報を格納する構造体の配列である。この变数には用例 $s_{i}$ の最大キー ワード含有数 $R(i) . k w d \_n u m$, その変位合計 $R(i) . d e v$, キーワード群の出現位置 $R(i)$.kwd_list を記録する (c7) 。

検索処理の中心部分は (c1-c10) である.キーワード数 $N$ の用例を検索するために開始 キーワード id を（c2）で設定している。このあと各用例 $i$ のでこのキーワード id に属す るノードから最適経路を探索している（c5）。検索開始キーワード id はキーワード数の緩和 （d6）に伴って 1 から順に増加するように設定されている（c2）。このため（性質 2） から用 
表 2 検索時間の比較 (秒)

\begin{tabular}{l|rrr}
\hline \hline 手法 & \multicolumn{1}{|c}{ AND } & AND+W & AND+W+D \\
\cline { 2 - 4 } 総時間 & $25,573.1$ & $33,201.6$ & $33,426.9$ \\
一回の緩和の平均時間 & 2.33 & 3.02 & 3.04 \\
\hline
\end{tabular}

例 $i$ でキーワード数 $N$ の経路が見つかった場合に，すでに同数の解が以前の開始キーワード id $(\{1, \ldots, M-N\})$ での探索で発見されている可能性がある。そこでこのような場合には変 位合計の小さい解だけを残す処理を行っている（c6-c7）.

図 2 の矢印で示す経路と変位は，キーワード id 1 のノードを開始点として最適経路を求め た結果である. 用例 1 と 2 についてはキーワード数 3 の解が, 用例 3 と 4 についてはキーワー ド数 4 の解が求められている.

以上のように本手法はキーワードを最大限含む順に解を求めている．多くの場合利用者は条 件緩和の途中で検索を打ち切るので，この順序で解を求めている。ただしこの手法では用例の ノード集合を最初に全部保持するためデータベースの大きさによってはメモリの消費が問題に なる可能性がある。この場合には各用例の最適解を最初に求めるなど変更する余地はある。い ずれにせよ動的計画法を利用すれば実用的な速度で解を求めることができる.

\section{5 検索実験}

\section{1 実行時間}

$\mathrm{AND}$ 検索, $\mathrm{AND}+\mathrm{W}$ 検索, $\mathrm{AND}+\mathrm{W}+\mathrm{D}$ 検索を対象に検索時間を評価した. $\mathrm{AND}+\mathrm{W}$ 検 索は $\mathrm{AND}+\mathrm{W}+\mathrm{D}$ 検索アルゴリズムをほぼそのまま利用して作成した． AND 検索はキーワー ドのノード集合を作成する過程で出現キーワード数を計数することで実現した。

検索対象データベースは 1995 年 3 月から 1997 年 2 月までに収集した日本語ニュースであ る (表 1). 入力したのは 1997 年 3 月のニュース記事からランダムに選んだ 500 記事の各先頭 行 500 行である.これらの記事は検索対象データベースに含まれていない. また入力の平均文 字数は 92.7 文字と長い.このためキーワードが完全一致する用例はほとんどない。

実験手順は以下のとおりである。入力の各文を形態素解析して自立語キーワードを抽出す る.そして各文でキーワード数 1 になるまで条件を自動的に緩和しながら検索を行ってその累 積時間を計測した ${ }^{10}$. 結果を表 2 に示す。緩和の合計回数は 3 手法で等しく 10,989 回である.

この表から語順を考慮した AND+W 手法と AND+W+D 手法でも AND 検索にくらべて 約 1.3 倍の時間増だったことがわかる。また $\mathrm{AND}+\mathrm{W}$ と $\mathrm{AND}+\mathrm{W}+\mathrm{D}$ を比較すると，時間の 差はほとんどなく変位の有無の影響はほとんどなかったことがわかる.

10 利用したワークステーションの記憶容量は $256 \mathrm{MB}$ であり, 処理速度は SPECint92 = 202.9, SPECfp92=259.5 で ある。 
表 3 各キーワード数での検索用例数（500 入力での合計）

\begin{tabular}{r|r|r}
\hline \hline キーワード数 & \multicolumn{1}{|c|}{ AND } & AND+W $(+\mathrm{D})$ \\
\hline 1 & $54,374,495$ & $59,258,536$ \\
2 & $13,923,270$ & $11,338,161$ \\
3 & $3,470,894$ & $2,088,640$ \\
$\vdots$ & $\vdots$ & $\vdots$ \\
\hline
\end{tabular}

1 回の緩和，すなわち利用者が 1 つキーワードを減少するよう指示した時に要した平均 検索時間 (総時間 $/ 10,989$ ) を 2 行目に記した。これによれば AND 検索で 2 秒, AND $+\mathrm{W}$, $\mathrm{AND}+\mathrm{W}+\mathrm{D}$ で 3 秒程度である。ただし総時間にはキーワードの出現位置をディスクからメモ リに転送する初期処理の時間を含めており，この時間がかなりの部分を占めている。初期処理 が終了した後の 1 回の緩和に要する時間は語順と変位を考慮しても 1 ないし 2 秒であり実用上 満足できる速度であった。 以上の実験より語順と変位を考慮してもAND 検索なみに十分高速 に検索できることを確認した。

\section{2 検索文数の絞り込み効果}

4.3 節の終わりに述べたようにキーワード数を 1 まで緩和すれば, AND, AND+W, $\mathrm{AND}+\mathrm{W}+\mathrm{D}$ 手法で検索できる用例集合は同じである。しかし実際にはキーワード数の大きな ところで検索を打ち切るので利用者の見る用例数は語順の制約の有無で違ってくる．この違い を前節と同じ入力を使って評価した。

語順を考慮した手法 AND+W ${ }^{11}$ と AND 検索それぞれについて, 各キーワード数での検索 用例数を計測した．結果を図 4 に示す．検索用例数は入力 500 文で合計したものである．横軸 はキーワード数で縦軸は対数を取った検索数である.また，このグラフの一部の検索用例数を 表 3 に示す.

アルゴリズムの説明で述べたように，文は含有キーワード数が最大の時に一度表示するだけ である.このため図 4 の 2 つのグラフの面積は等しくなる. 表 3 から明らかなようにキーワー ド数 1 の部分で AND $+W$ 検索の検索用例数が AND 検索の結果を大きく超えている.この結 果キーワード数が 1 以外の部分では AND $+\mathrm{W}$ 検索の検索数は AND より小さく押さえられて いる.すなわち語順制約を使うことでキーワード数が 1 より大きい部分で検索結果数を絞り込 むことができたことが確認できる。

しかし，語順による絞り込みの効果が十分であるとは言えない.キーワード数が小さい部分 での絶対的な検索数が大きいのが問題である. 例えば 3 語のキーワードで検索する用例数は平 均で $4,177 （=2,088,640 / 500)$ に達した。このような用例も検索する可能性があるため絞り

$11 \overline{\mathrm{AND}+\mathrm{W} \text { と AND+W+D }}$ は同じキーワード集合に対して同じ用例集合を検索するので，ここでは AND+W で代表 する. 


\section{Retrieval count}

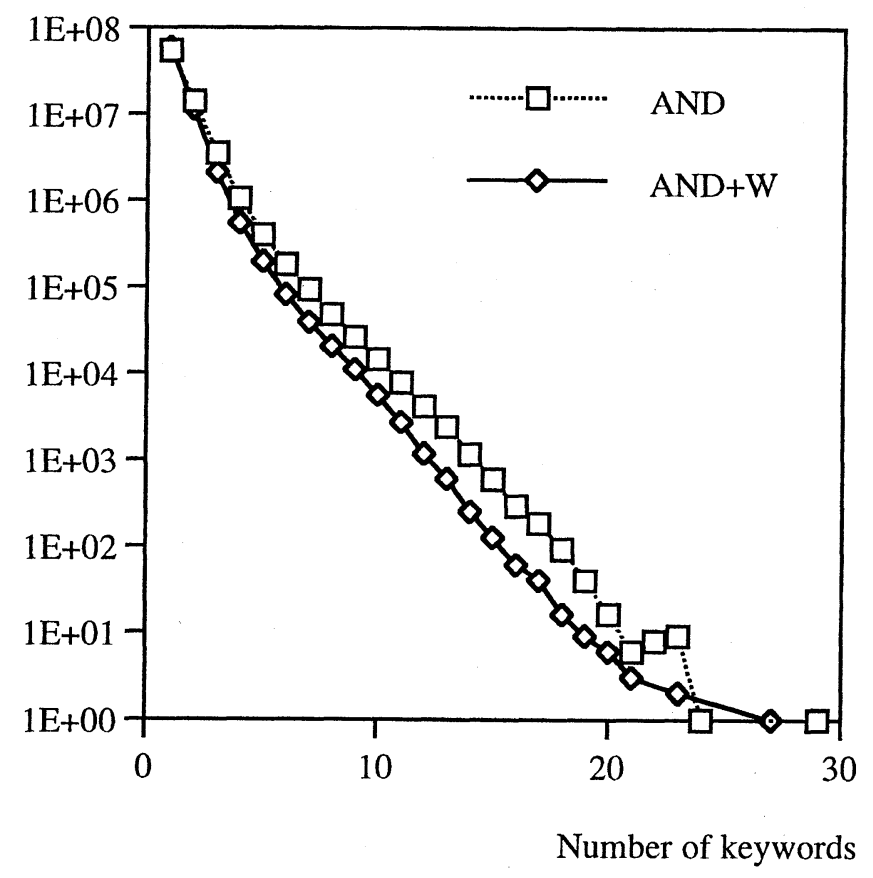

図 4 各キーワード数での検索用例数（500 入力での合計）

込み効果は十分でない，逆に50 程度の検索用例数を許容すると仮定すればキーワードの語順 を考えない場合でも 10 語以上含む入力であれば許容範囲の検索数となる．語順を使った場合 は 8 語以上で許容範囲となる.

\section{3 検索結果の満足度}

語順に変位の制約を加えると検索結果に優先順位をつけることができる。この順位が妥当で あれば検索用例数の多さの問題は解決できる.そこで著者らはこの順位の妥当性を検証するため 3 手法の検索結果の満足度の高さを主観的に評価して比較した。実験要領は以下の通りである.

- 被験者

翻訳者 3 名.このうち 1 名はニュース翻訳の経験が豊富である. 残りの 2 名はニュース 翻訳を直接担当しているわけではないが翻訳の経験は豊富である。いずれの被験者も検 索手法については知らされていない.

- 入力表現

現実の入力を想定して 58 の日本語表現を作成した。具体的には先の実験で使用した 500 文から文をランダムに抽出し，それらの一部を切り出して作成した。すなわちカットア 
表 4 相対評価結果

\begin{tabular}{c|ccc}
\hline \hline 被験者 & AND & AND+W & AND+W+D \\
\hline A & 2.88 & 2.94 & 3.60 \\
B & 2.99 & 3.07 & 3.90 \\
C & 3.07 & 3.21 & 3.80 \\
\hline 平均 & 2.98 & 3.08 & 3.77 \\
\hline
\end{tabular}

ンドペーストで入力することを想定した. 長さの平均は 22.6 文字, 最大の入力は 62 文 字，最小の入力は 14 文字である.

- 出力

一つの入力に対して各 3 手法の上位 5 個の日本語検索結果を印刷して提示した。この時, 各手法の検索結果の提示順序を 1 つの入力ごとに変更して, 検索手法と結果の対応がわ からなくなるようにした。 また照合したキーワードをく>で囲んで表示した．被験者は 最初のキーワードから最後のキーワードが出現した区間を中心に評価した。これはキー ワードで検索した部分以外に偶然類似した部分があった場合にこれを評価しないためで ある。

- 評価手法

検索した部分の正しい英訳があると想定したときの満足度を次の 2 種類で評価した。

- 相対評価

3 手法すべての結果を見て, 最も満足度の高い結果を 5 点として, 以下この結果 との満足度の差を下記の要領で評価した。

$\begin{array}{lll}\text { 全く差がない } & \\ \text { わずかに差がある } & \text { (わずかに劣る) } & 4 \\ \text { 差がある } & \text { (劣る) } & 3 \\ \text { かなり差がある } & \text { (かなり劣る) } & 2 \\ \text { 非常に差がある } & \text { (非常に劣る) } & 1\end{array}$

- 絶対評価

翻訳を行うときに英訳があればどの程度役に立つかを以下の 5 段階で絶対評価 した。

$\begin{array}{lll}\text { 非常に役に立つ } & \text { (非常に良い) } & 5 \\ \text { かなり役に立つ } & \text { (良い) } & 4 \\ \text { まあ役に立つ } & \text { (ふつう) } & 3 \\ \text { あまり役に立なない } & \text { (悪い) } & 2 \\ \text { 全然役に立たない } & \text { (非常に悪い) } & 1\end{array}$

評価シートの実例を付録に示す. 3 名の評価結果の平均值を表 4 と 5 に示す. 
表 5 絶対評価結果

\begin{tabular}{c|ccc}
\hline \hline 被験者 & AND & AND+W & AND+W+D \\
\hline $\mathrm{A}$ & 2.78 & 2.81 & 3.13 \\
$\mathrm{~B}$ & 2.84 & 2.98 & 3.44 \\
$\mathrm{C}$ & 3.02 & 3.10 & 3.44 \\
\hline 平均 & 2.88 & 2.96 & 3.34 \\
\hline
\end{tabular}

表 6 相対評価の $t$-值

\begin{tabular}{c|rr}
\hline \hline & AND & AND+W \\
\hline AND+W & 1.55 & \\
AND+W+D & 13.28 & 11.77 \\
\hline
\end{tabular}

表 7 絶対評価の $t$-值

\begin{tabular}{c|rc}
\hline \hline & AND & AND+W \\
\hline AND+W & 1.44 & \\
AND+W+D & 8.73 & 7.23 \\
\hline
\end{tabular}

また各手法の違いを検定するため平均值の差の $t$-検定を行った. 手法間の $t$-值を表 6 と 7 に示す ${ }^{12} . t_{0.025}(\infty)=1.960$ であるからどちらの表でも AND+W+D と AND, AND+W+D と $\mathrm{AND}+\mathrm{W}$ の組み合わせでは有意水準 $5 \%$ で帰無仮説（平均值に差がない）を棄却できる ${ }^{13}$. 一方, $\mathrm{AND}$ と $\mathrm{AND}+\mathrm{W}$ では $5 \%$ 有意水準の衰却はできない. 以上の結果より次のことが結 論できる。

- $\mathrm{AND}$ 検索と AND 検索に語順制約を加えた $\mathrm{AND}+\mathrm{W}$ 検索では $\mathrm{AND}+\mathrm{W}$ 検索の方が満 足度が高くなる傾向は認められたが，統計的に有意な差はなかった。

- $\mathrm{AND}+\mathrm{W}+\mathrm{D}$ 検索の満足度は $\mathrm{AND}$ 検索と $\mathrm{AND}+\mathrm{W}$ 検索のいずれの満足度より高く なった。またこれは統計的に有意な差であった。

以上より提案手法の精度が最も高かったと結論できる。

\section{4 議論}

本章の実験結果のまとめを示す.

・ 検索時間は AND 検索が有利であったが語順と変位を加えても 1.3 倍程度の時間増で あった。

・ 語順制約を追加することで検索結果を絞り込む効果は確認できた. しかし，短い入力に 対する絞り込み効果は十分ではなかった。

12 二つの母分散が等しい場合とそうでない場合で計算したところ表中の桁数で值は変わらなかった.

$13 t_{0.0005}(\infty)=3.291$ であり $0.1 \%$ であっても棄却できる. 
・ 変位の制約を加えると検索結果に順位付けができる。この効果を計測したところ有効性 を有意に検出できた。

今回の実験から，カットアンドペースト方式の入力では AND $+\mathrm{W}+\mathrm{D}$ 検索と AND 検索を 使うのが良いと著者らは考えている. AND $+\mathrm{W}+\mathrm{D}$ 検索は最も満足度が高かったからである. AND 検索は今回の満足度の実験の結果は一番低かった. しかし，速度の面は最優れている. また入力の表現が長い部分では検索結果の数も問題にならない。そこで長い表現を検索する場 合に AND $+\mathrm{W}+\mathrm{D}$ 検索を補完する意味で利用する価值があると考える.

一方 $\mathrm{AND}+\mathrm{W}$ 検索と $\mathrm{AND}+\mathrm{W}+\mathrm{D}$ 検索の両方を使う必要性は小さいと言える。両者は基 本的に同じ検索結果となるからである。ただし，これは本稿のように入力表現を原文のカット アンドペーストで作成する場合に限る。利用者が直接キーワード列を入力する場合には変位の 情報を使えない。このため語順だけを使った $\mathrm{AND}+\mathrm{W}$ 検索を使う必要も生じる ${ }^{14}$.

\section{6 関連研究}

類似用例提示型翻訳支援システムの提案はこれまで多くなされている (中村 1989; 隅田, 堤 1991; 寺濱, 小澤, 小嶋, 絹川 1992; 佐藤 1993; 武田, 古郡 1994; 兵藤, 池田 1994; 北村, 山本 1996; 青山, 徳田, 辻, 藤田, 杉村 1995) 。ここではこのようなシステムの中で著者らの検索の研 究と近い研究について比較を行う.

中村 (中村 1989) の研究は著者らの研究の出発点になったものである.この論文は用例検索 による翻訳支援の考え方と構成を示している，中村はこの論文で入力表現と用例が共有する自 立語の数に基づいて類似性を計算する手法を提案している．また，検索結果の順位を次の $3 つ$ の条件で整列している：1）構成語（本研究のキーワード）がその他の語をはさまない，2）用例 中の自立語の個数に対する構成語の数の比率，3）含んでいる構成語の数.このシステムを使つ た小規模な評価実験では長い (複数文節) 表現を入力した場合に検索結果が「あいまい」となっ て被験者の評価が低くなったと報告している。これは検索結果の効果的な絞り込みの必要性を 示唆した結果である，著者らはこれに対して語順と変位を考慮した検索を提案しその有効性を 確認した。

隅田ら (隅田, 堤 1991) は表現辞典の用例文を検索する翻訳支援システムを提案している. 著 者らとの主要な違いは 2 点ある．1）用例文はニュースの記事に比べて短く入力も単文に近い用 例を想定している点，2）検索では構文的な類似性を重視している点である．類似検索は入力の 自立語を順次無視して最後に付属語列のパターンまで検索条件を緩和する手法を採用している. ここで語順は考慮していない.

隅田らは構文情報の把握に助詞を利用している。これは短い用例を対象にした場合に有効 であるが，著者らのように長い用例を扱う場合には不適切である。なぜなら長い用例では表層 14 著者らのシステムにもキーワードを直接入力する機能があり,この場合には AND と AND+W 検索を利用している. 
の助詞だけで主要な構文構造を把握することができないからである．また，助詞は極めて多く の場所に出現するためこれを使う処理は遅くなる問題もある. 実際著者らのシステムで助詞を キーワードに含めて検索実験を行ったところ自立語だけを対象にする場合の約 23 倍の時間が かかることが分かった。

佐藤 (佐藤 1993) は文字を連続して多く共有する 2 つの文を近いと考えた「最適照合検索」 を提案している。この論文では 1 文字を照合単位としかつ順序を考虑した照合手法 (CTM1) と 2 文字と 3 文字を照合単位とし，順序を無視した照合手法 (CTM2) を提案している．また どちらの手法も文字列が連続して出現することを類似性の条件に含めている.

文字と単語の違いを無視すれば，著者らの語順と变位を考えた手法が CTM1 に，語順を無 視した手法が CTM2 に対応する．またこの二つの手法の検索結果の違いを次のような実験で検 討している．1）100 個の入力をそれぞれ検索し，上位 5 つの類似表現を得る，2）その英訳の 中で最良の英訳の有用性を 4 段階で主観評価する ${ }^{15}$.

実験結果よると二つの手法の有用性は同等もしくは CTM2 の方が若干良かったとなってい る．著者らの結果と比べると出現順序を考えない CTM2 の結果が良いのは意外である．原因は 用例データベースの違い，入力表現の違い，評価法の違いがあるため断定できないが， CTM2 の文字列の連続性の条件が貢献している可能性がある。この条件が著者らの变位と対応したと 考えられる，著者らの実験結果でも語順だけでは効果が薄く変位が有効であった点を考えると 両者の実験結果に矛盾はない。

\section{7 おわりに}

翻訳支援を目的とした類似文検索手法を提案してその有効性を実験で確認した。提案したの は入力と用例のキーワードの共有数，語順，その变位を類似性の基準とした検索手法である。 提案手法は入力文の形態素解析以外は表層文字列の一致を使うため，高速かつ頑健という利点 を持つ.

今後の課題を述べる．現在はすべての自立語を同等の重要性を持ったキーワードとして検索 を実行している。しかし，利用者が知りたい表現が特定のキーワードを含む場合があろう。ま た，動詞を含んだ表現で条件緩和をする場合に，一般的に動詞は削除しない方が良いと考えら れる。このような特別な条件や経験則を現在の処理に追加するのは今後の課題である。このよ うな変更は内容が明らかになれば現在の枠組みで簡単に実現できると考えている。

現在，本検索部分を含んだ日英翻訳支援システムをニュースの翻訳現場で実際に使用し始め ている，そこで検索条件の改良は実際の利用者の意見を取り入れて進めていきたいと考えてい る。また今回は日本語の検索部分だけの評価を行ったが, 実際の英語の出力を使ってシステム 全体の評価も行う予定である。これについては別途報告したい.

15 利用者は一つの有用な対訳が得られれば十分という考えによる。一方, 著者らは多様な対訳の検索を重要視している. 
今回は日本語を対象にした検索システムを報告した。今回の内容は言語に依存した部分がほ とんどないためその他の言語への応用も簡単である。すでに英語の検索部分を作成しており， その有効性を調査したいと考えている.さらにその他の言語への適用可能性も検討したい.

\section{付録 評価シートの例}

この場合は $\mathrm{AND}+\mathrm{W}, \mathrm{AND}+\mathrm{W}+\mathrm{D}, \mathrm{AND}$ の順に検索結果を表示している．評価文の最初 の括弧付の数字が相対評価, 2 番目の数字が絶対評価の值を示す.

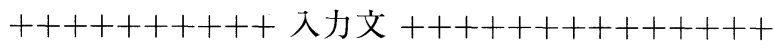

IN 事故のあった施設の中を調査しました。

++++++++++ キーワード ++++++++++

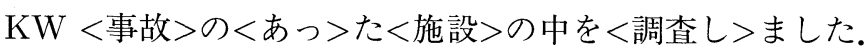

++++++++++ 検索文 ++++++++++++++

SR 2-1 (1) (2) この研究グループは, 車に携帯電話を備えていて, 軽い物損 $<$ 事故 $>$ を起こ したことの<ある $>$ ドライバー六百九十九人について，事故のデータと通話記録を＜調査し $>$ ま した。

SR 2-2 (1) (2) 公海上でおきた今回の<事故>の原因調査は国際条約で船籍の<ある>ロシア が行うことになりますが事故の原因を特定するためには船首部分の破断面などを詳しく分析す る必要があるため, 運輸省では引き続き外交ルートを通して共同でく調査す >ることをロシア側 に求めていくことにしています.

SR 2-3 (1) (2) 埼玉県内では小山代表が理事長を務める特別養護老人ホームがくある>北本市 でもきょう臨時の市議会が開かれ，＜施設＞建設に至る経緯や運営について<調查す＞る特別委 員会を設けたほか, 現在同じ社会福祉グループの特別養護老人ホームの建設が進んでいる上福 岡市も，市役所の中に対策委員会を設置して補助金の使い途などについて調查を始めています.

SR 2-4 (1) (2) 埼玉県内では小山容疑者が理事長を務める特別養護老人ホームがくある>北 本市でもきょう臨時の市議会が開かれ，＜施設＞建設に至る経緯や運営について<調査す＞る特 別委員会を設けたほか，現在同じ社会福祉グループの特別養護老人ホームの建設が進んでいる 上福岡市も，市役所の中に対策委員会を設置して補助金の使い途などについて調査を始めてい ます。

SR 2-5 (1) (1) 去年, 山形県でジェット機の低空飛行が原因で女性が馬から落ちて怪我をし たく事故>について在日アメリカ軍はこのジェット機がアメリカ軍機でくある>ことを認め被害 者に賠償の支払いに応じる意向を防衛＜施設＞庁に伝えてきていたことが分かりました.

++++++++++ 検索文 ++++++++++++++

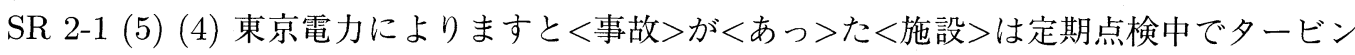
などを分解して組み直し再び発電を始めるための試運転中に事故が起きたということです。

SR 2-2 (3) (3) 警察庁は今年六月に全国で起きた死者やケガ人のでたおよそ六万二千件の交 
通事故を対象に携帯電話が原因とみられる<事故 $>$ がどの程度くある $>$ のか初めて<調查し >ま した。

SR 2-3 (3) (3) 警察庁は今年六月に全国で起きた死者やケガ人のでたおよそ六万二千件の交 通事故を対象に携帯電話が原因とみられる<事故 $>$ がどの程度くある $>$ のか初めて<調查し >ま した.

SR 2-4 (1) (1) このため, ノースウエスト航空では問題のエンジンをアメリカのミネアポリ スに<ある>本社の整備＜施設 $>に$ 運んで詳しく<調査す >る事にしたもので，きょう，機体か ら問題のエンジンを取り外して新しいエンジンと取り替え，このエンジンをきょうにもミネア ポリスに向け送る事にしています。

SR 2-5 (1) (1) それによりますと, 去年の六月二十四日, ワシントン州のフェアチャイルド 空軍基地の上空で航空ショーのリハーサル飛行をしていたB一五十二戦略爆撃機が墜落し乗員 四人全員が死亡した<事故〉で，墜落地点は基地にくある>核兵器の貯蔵＜施設＞のすぐ近くで， 距離はわずか十五メートルしか離れていなかったいうことです.

++++++++++ 検索文 ++++++++++++++

SR 2-1 (1) (1)このうち, 原子力の問題に取り組んでいる原子力資料情報室は, 地球規模で

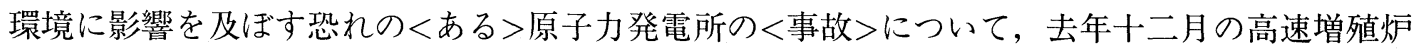
「もんじゅ」のナトリウム漏れ<事故 >を例に挙げて $\mathbf{v}$ 地元への<事故 $>$ 報告を義務付けるこ とや原子力＜施設 $>$ での<事故 $>$ の原因を<調査す $>$ 第三者機関を設けること，それにマ民 間の調査に対しても情報を公開することなどを盛り込んだ「原子力＜施設 $><$ 事故 $>$ 対応法」の 制定を提案しました。

SR 2-2 (1) (1) 沖縄県に<ある>アメリカ軍基地の排水管から高い濃度の有害物質 P C B が 検出された問題できょう基地をかかえる沖縄県内の自治体の代表らが防衛く施設 $>$ 庁を訪れ，ア メリカ軍による相次ぐ事件やく事故>の防止に全力をあげるよう要請しました.

SR 2-3 (1) (1) N H K はこの問題の実態をつかむため保健所を持ち処理＜施設>に許認可権 がくある>各都道府県や市あわせて八十二の自治体を対象にアンケート方式で＜調查し>すべて の自治体から回答を得ました。

SR 2-4 (1) (1) N H K はこの問題の実態をつかむため保健所を持ち処理＜施設>に許認可権 がくある>各都道府県や市あわせて八十二を対象にアンケート方式でく調査し>すべての自治体 から回答を得ました。

SR 2-5 (1) (1) これに対して池田外務大臣は「在日アメリカ軍は今回の<事故>で使用され たのと同様の劣化ウランを含む砲弾を日本国内の一部の<施設 $>に$ 所蔵しているがこれは日本が 攻撃を受けるなど緊急事態が発生した場合には使用する必要がくある>ものでそうした意味で撤 去を求めるのは適当ではない」と述べ，アメリカ軍に対して，日本国内に所蔵している同種の 砲弾の撤去は求めないという考えを示しました。 
謝辞 本研究は第一著者が NHK 放送技術研究所勤務中に行った研究をまとめたものです。本 論文をまとめる機会を与えていただいた ATR 音声翻訳通信研究所の山本誠一社長と横尾昭男 室長に感謝いたします。また，プログラムの作成と実験に協力していただいた株式会社 KIS の 松田伸洋氏に感謝いたします。

\section{参考文献}

Isabelle, P. and Church, K. W. (1997). "Special issue on: New Tools for Human Translators." Machine Translation, 12 (1-2).

Kay, M. (1997). "The Proper Place of Men and Machines in Language Translation." Machine Translation, 12 (1-2), 3-34.

Salton, G. and McGill, M. J. (1983). Introduction to Modern Information Retrieval. McGrawHill.

Tanaka, H. (1997). "An Efficient Document Clustering Algorithm Based on the Topic Binder Hypothesis." In Proceedings of the Natural Language Processing Pacific Rim Symposium 1997, pp. 387-392.

Tanaka, H., Kumano, T., Uratani, N., and Ehara, T. (1999). "An Efficient Document Clustering Algorithm and its Application to a Document Browser." Information Processing and Management, to appear.

兵藤安昭, 池田尚志 (1994). “係り受け構造の照合に基づく用例検索システム TWIX.” 電子情報 通信学会論文誌, J77-D-II (5), 1028-1030.

隅田英一郎, 堤豊 (1991). “翻訳支援のための類似用例の実用的検索法.”電子情報通信学会論文 誌, J74-D-II (10), 1437-1447.

田中英輝, 熊野正, 松田伸洋 (1997). “階層分割型クラスタリングを使った文書ブラウザ.”情報 処理学会第 55 回全国大会, 3 巻, pp. 150-151.

寺濱幸徳, 小澤邦昭, 小嶋弘行, 絹川博之 (1992). “英文作成支援システムにおける例文検索法 式.”情報処理学会第 45 回全国大会, 3 巻, pp. 145-146.

青山昇一, 徳田克己, 辻敦生, 藤田公一, 杉村領一 (1995). “連語検索結果の評価手法と提示優先 順位決定アルゴリズム.”情報処理学会 自然言語処理研究会報告 95-NL-105, pp. 15-20. 長尾真 (編) (1996). 言語統計のとり方, 2 章, p. 20. 岩波講座ソフトウエア科学. 岩波書店. 熊野正, 田中英輝, 浦谷則好, 江原暉将 (1997). “日英放送原稿翻訳支援のための類似用例提示シ ステム.”言語処理学会第 3 回年次大会, pp. 529-532.

熊野正, 田中英輝, 金淵培, 浦谷則好 (1996). “日英ニュース原稿の対訳コーパス化に関する基礎 調査.”言語処理学会第 2 回年次大会, pp. 41-44. 
中村直人 (1989). “用例検索翻訳支援システム.” 情報処理学会第 38 回全国大会, 1 巻, pp. 357-358.

北村美穂子, 山本秀樹 (1996). “対訳文書の文・単語対応付け技術を利用した対訳用例検索シス

テム.” 情報処理学会第 53 回全国大会, 2 巻, pp. 385-386.

武田明子, 古郡廷治 (1994). “例文をもとにした英文書作成支援システム.”情報処理学会論文誌，

35 (1), 53-61.

佐藤理史 (1993). “用例検索による日英翻訳支援システム CTM2-部分列インデックスを用いた 最適照合検索.”テクニカル・レポート IS-RR-93-61, 北陸先端科学技術大学院大学 情報 科学研究科.

\section{略歴}

田中 英輝： 1982 年九州大学工学部電子工学科卒業. 1984 年同大学院修士課程 修了. 同年, 日本放送協会に入局. 1987 年同放送技術研究所勤務. 1997 年 ATR 音声翻訳通信研究所勤務. 現在第 4 研究室主任研究員. 機械翻訳, 機 械学習, 情報検索の研究に従事. 工学博士. 情報処理学会, 人工知能学会各 会員.

熊野 正: 1993 年東京工業大学工学部情報工学科卒業. 1995 年同学理工学研究 科情報工学専攻修士課程修了. 同年, 日本放送協会に入局. 放送技術研究所 勤務. 自然言語処理, 人工知能の研究に従事. 情報処理学会, 人工知能学会 各会員.

浦谷 則好： 1975 年東京大学大学院修士課程（電気工学）修了。同年，日本放 送協会に入局. 1979 年同放送技術研究所勤務。1991 年より 3 年間 ATR 自 動翻訳電話研究所ならびに音声翻訳通信研究所に勤務。現在，NHK 放送技 術研究所ヒューマンサイエンス主任研究員. 情報検索, 自然言語処理の研究 に従事. 工学博士. 情報処理学会, 電子情報通信学会, 映像情報メディア学 会各会員.

江原 暉将: 1967 年早稲田大学第一理工学部電気通信学科卒業. 同年, 日本放 送協会に入局. 1970 年より放送技術研究所に勤務。現在，ヒューマンサイエ ンスグループ主任研究員．かな漢字変換，機械翻訳，音声認識などの研究に 従事. 工学博士. 本会評議委員. 情報処理学会, 機械翻訳協会, 電子情報通 信学会, 映像情報メディア学会各会員. 